\title{
Customer Satisfaction with Branch Office Services in Higashihiroshima, Hiroshima Prefecture
}

\author{
Yasutoshi Moteki ${ }^{1}$
}

Accepted: 18 October 2021

(C) The Author(s) 2021

\begin{abstract}
This study empirically investigates the major factors that determine customer satisfaction in local government offices in Japan by using three categories of questions. They referred to customer satisfaction studies worldwide, especially to the expectancy disconfirmation model, the SERVQUAL model, and subsequent methods that emphasize customer's direct experience. The on-site surveys were conducted at the Kurose branch office in Higashihiroshima City. A total of 240 responses were obtained over six weekdays. The regression analysis showed that staff responses and explanations were the most influential, followed by aspects related to the physical office and service delivery quality (adjusted $R^{2}$ value of .51 ).
\end{abstract}

Keywords Customer satisfaction - Counter service · Principal component analysis · Local governments $\cdot$ Direct experience

\section{Introduction}

A government evaluation system was implemented in Mie prefecture, Japan, during the 1990s. This was followed by the implementation of government evaluation systems in municipalities throughout the nation, thus influencing the central government to enact a law requiring all ministries to carry out policy evaluations in 2002. In this context, several surveys have shown that large municipalities are more proactive in introducing evaluation systems (Moteki, 2015; Tabuchi, 2010).

In Japan, government evaluation systems are typically introduced from a business administration standpoint, emphasizing the plan-do-check-act (PDCA) cycle. While the PDCA acronym is widely used in many areas of Japanese governance, the term originated in the private sector as part of the business improvement (Kaizen) movement. Adherents of this notion usually highlight the check (C) function, that

Yasutoshi Moteki

moteki@hiroshima-u.ac.jp

1 School of Humanities and Social Sciences, Hiroshima University, Higashihiroshima, Hiroshima, Japan 
places extra importance on the need for evaluation in many public organizations. As such, government evaluation systems are commonly found in smaller municipalities, while some larger municipalities have abolished them after successfully improving specific programmes. Recently, more emphasis has been placed on diversifying methods as well as developing and exploring specific methods, including programme satisfaction surveys targeted at citizens, selective project analyses that use logic models, and systems designed for evidence-based policymaking. Under these circumstances, an increasing number of local governments are now focusing on customer satisfaction by offering specialized counter services and conducting on-site office surveys to improve their operations.

This study employed a questionnaire survey to gauge the level of customer satisfaction with the counter services provided at a local government branch office, specifically by following the method implemented in the business management field when investigating private companies (for details, see Takahashi \& Kawasaki, 2019). Noda (2013) and others have already used relevant academic concepts to examine the overall satisfaction levels reported by residents when dealing with local governments, while many local governments in Japan (including the Higashihiroshima City government) have conducted their own citizen satisfaction surveys, typically focused on policy issues (Sesaku Manzoku-do Chosa [Programs Satisfaction Survey]). More specifically, municipal residents are asked to respond to questionnaires concerning a variety of local government programmes. Their answers are then used to analyse each programme based on four categories that cover elements related to both importance and satisfaction.

Some municipalities in Japan have started to conduct more specific surveys focusing on customers' direct experience. In Hiroshima prefecture, for example, Kumano Town implemented an on-site survey over a two-month period in 2009, the results of which were published on their official website (Kumano Town, 2009). Ogaki City (2014) in Shiga prefecture also conducted a mail-based questionnaire survey among its 2,000 residents to aid in the construction of a new municipal building (response rate of $47.7 \%$ ). Respondents were asked about a variety of relevant items, including whether they had previously visited the city hall, the purpose of their visit, means of transportation used, and their experiences during the visit.

Following the above literature, this study examined customer satisfaction with the counter services provided at a local government office by implementing an on-site survey at the physical branch location (Shisho). Based on local ordinances, shisho are usually located in the same areas as former local municipality offices prior to amalgamation. While there, residents may apply for and consult with servicepersons regarding the available administrative services.

Here, it is appropriate to outline and provide a brief history of the Kurose branch office of the Higashihiroshima City government, where the research was conducted. In February 2005, the five towns of Kurose, Fukutomi, Toyosaka, Kawachi, and Akitsu merged with Higashihiroshima City to form the new city of Higashihiroshima, which contained a population of 188,966 as of 31 August 2020 (Higashihiroshima City Government, 2016, 2020). It is now the fourth most populous city in Hiroshima prefecture. Spanning an area of 635.16 square kilometres, it covers land from the inland Kamo plateau to the sea of Akitsu, which was referenced in songs 
from the ancient Man'yoshu anthology compiled by Abe no Tsugumaro in $736 \mathrm{CE}$ (Hiroshima Prefectural Government, 2007). The second-class Kurose River is fed by a mountain in the former Saijo Town area and flows through what is now Kurose Town before reaching the sea in Kure City. At present, Kurose Town (Kurose cho) is part of Higashihiroshima City. Before the merger, Kurose Town was in the process of forming a large-area administrative union [Koiki Gyosei Kumiai] with Higashihiroshima City, Fukutomi Town, Toyosaka Town, Daiwa Town, and Kawachi Town (Kurose Town, 2001, p. 23), and was engaged in a cooperative relationship with the former Higashihiroshima City. Each of the five towns that consolidated in 2005 now have their own government branch offices that can perform nearly all the same functions that the individual towns handled before the merger. The first four towns that merged in 1974 also have satellite offices (Schuccho-sho), which have limited administrative functions. Branch offices are often established in areas that were occupied by the former municipalities prior to the merger, thus maintaining the same quality of government services for some time. Some municipalities have even established general branch offices (Sogo Shisho), thereby expressing that they hold particularly strong administrative powers and functions when compared with normal branch offices in other municipalities.

In sum, this study conducted a questionnaire survey among residents of Higashihiroshima City, specifically covering four main categories related to their level of satisfaction with the counter services provided at the local government branch office in Kurose. The affecting factors thus obtained were statistically analysed through a selective multigroup principal component regression analysis developed by Professor Emeritus Takahashi, a combined principal component analysis and multiple regression analysis (Takahashi \& Kawasaki, 2019). This study, therefore, explored the determinants of customer satisfaction for the purpose of obtaining insights for how to improve administrative practices, concerning the desired state of those offices in older areas within the merged municipalities mentioned earlier.

\section{Literature Review}

Research on 'customer satisfaction' with the public administration has been influenced by the results of studies on private sector marketing. Research on the satisfaction of corporate customers in the private sector began with Oliver's prominent study, which focused on the discrepancy between expectations and subsequent perceptions of performance as a determinant of customer satisfaction (Oliver \& Winer, 1987). Zeithaml (1988) showed the influence of intrinsic and extrinsic attributes on 'perceived quality' in the figure titled 'A Means-End Model Relating Price, Quality, and Value' (p. 4). The 'hardware' in this research is represented by Zeithaml's extrinsic attributes.

Oliver's research was later published in a book titled 'Satisfaction' in 2010, with a second edition published in 2015 (Oliver, 2015). Based on this expectancy-disconfirmation theory, studies have been conducted in the field of public administration, considering citizens as customers (Van Ryzin, 2004, 2006; Van Ryzin \& Immerwahr, 2007; Van Ryzin et al., 2004). Morgeson (2012) empirically 
examined respondents' political ideology, party identification, and overall trust in the federal government as additional determinants of satisfaction. Kelly (2005) as well as Kelly and Swindell (2002) examined related factors, such as unsatisfied customers and regional differences concerning customer satisfaction in public administration.

Similar to Oliver's research and methodology focusing on expectations, Parasuraman et al.'s (1988) SERVQUAL had a significant impact on subsequent research on service quality. This method measures service quality using five groups (tangibles, reliability, responsiveness, assurance, and empathy) through multiple questions. The hardware category in the present study falls under the 'tangibles' category, while the multiple human factor-related categories (assurance, empathy, and responsiveness) in the SERVQUAL scales are grouped under the software category. The SERVQUAL model, which represents the five dimensions of service quality, is mentioned in the latest edition of the service marketing textbook and is well established in this field (Wilson et al., 2021, pp. 89-91). In the field of public administration, a model based on SERVQUAL was widely used by the Scottish council services in the United Kingdom (Wisniewski, 2001).

Since 2010, research on customer satisfaction in the public sector has been shifting its focus to service experience rather than satisfaction itself. In the medical field, a public sector, the study of patient experience (PX) has been developed from studies on patient satisfaction (Manary et al., 2013; Wolf \& Jason, 2014). Journals specializing in this field emerged (the Patient Experience Journal). In Japan, a standardized questionnaire index on patient experience was developed. The research in this paper, similar to recent studies on customer experience, assumes that expectations are important for satisfaction; however, it focuses on the customer's direct experience and examines whether there are differences in the importance of other major factors in different environmental conditions.

In the field of public administration research in the United States, Wagenheim and Reurink (1991) focused on the rationale of customer satisfaction. Their study divided customers into internal and external customers, proposing the hypothesis that the satisfaction of both types of customers' service needs leads to organisational efficiency and effectiveness, based on the discussions of previous studies. Noda (2013) published information on citizen satisfaction from a general perspective in the Japanese context and has since continued to publish administrative research on citizen satisfaction (Noda, 2014, 2019). His research partly aimed at testing the expectancy-disconfirmation theory in the Japanese administrative context. More specifically, it included a study that investigated statements made by politicians and photographs of road management practices to analyse the relationship between expectations, performance, and customer satisfaction (Noda, 2019). Additionally, he examined 2,997 responses from residents of cities in the Tokyo Metropolitan area based on an Internet survey designed considering populational and age ratios (Noda, 2014). Meanwhile, Yamaoka (2015) focused on a program satisfaction survey, from which data were used to calculate satisfaction and importance indices for municipal programmes. Yamaoka and Hideshima (2012) employed an information management perspective to analyse the process by which customer satisfaction was improved at the local government level. 
In the context of the total quality management and Kaizen movements, customer satisfaction surveys and related research have become increasingly popular throughout the Japanese private sector. In this regard, Ono (2010) published work through the Nihon Keizai Shimbun (a daily leading newspaper specializing in economic and business fields) affiliates, showing that customer satisfaction knowledge was highly important for corporate employees in Japan. These studies specifically detailed notable customer satisfaction initiatives implemented by companies, such as Komatsu (a construction equipment manufacturing company), and were outlined in the annually conducted cross-industry survey of customer satisfaction (Japan Customer Service Index), which is managed by Nihon Seisansei Honbu (the Japan Productivity Centre). Indeed, customer satisfaction surveys are not only common throughout the corporate sector but have also become popular in the public sector. Many of these surveys have focused on the field of hospital management, with reference to examples of foreign practices. Notably, Maeda (2005) provided an overview of the field and presented the results of customer satisfaction surveys conducted in hospitals. Researchers and practitioners in the field recently shifted to a mindset focused on improving the customer experience, which is specifically referred to as patient experience, as it is based on actual events experienced at hospitals.

Studies have focused on customer/citizen satisfaction in the context of governments in other countries. The current study specifically referred to the framework developed by Mansor and Razali (2010), who conducted research in Malaysia using three groups of questions, each consisting of multiple question items of 5-point scale. Furthermore, a similar study was performed on customer satisfaction in the Malaysian public sector (Agus et al., 2007), which involved two different surveys targeted at customers and managers in government branches, revealing co-relationships among service quality dimensions, service performance, and customer satisfaction. Surapto (2014) conducted a survey in Indonesia among 200 residents from urban villages in South Tangerang. Other studies on customer satisfaction in public administration in Asia include Hsiao and Lin (2008) in Taiwan as well as Huque and Hayllar (1999) in Hong Kong. Cripps et al. (2004) led a similar study in Australia, implementing a mail-based survey among 1,500 residents under three local governments in the city of Perth. Results showed that customer satisfaction was higher in newer, smaller municipalities. Akinboade et al. (2012) used the allocation method, which considers the populational ratios of municipalities, to survey 1,000 citizens on the delivery of various public services (e.g. health, housing, and water). Their questionnaire used a seven-point grading method to measure satisfaction, ranging from completely dissatisfied to completely satisfied. Rhee and Rha (2009) used a critical incident technique (CIT), which is different from SERVQUAL, distributing a questionnaire to the beneficiaries and social workers of a local social welfare centre. The questionnaire was mailed to each facility. Their method was a case-focused technique intended to grasp public service quality.

As for academic research on the Kurose-cho area, Higashihiroshima City, which is this article's target research area, Abe (2004) conducted a study from the perspective of agricultural economics, especially Japanese agricultural history. He revised and published a collection of previous journal articles on agriculture, farming villages, and agricultural policy in Kurose Town - these studies mainly focused on the 
Edo period - as a book. Chapters 2-4 discuss water control projects using reservoirs in the Kurose-gumi, an administrative unit of the Hiroshima-han clan during the Edo period, consisting of 18 villages, and the rural economy, including teppou (gun) trading. In addition, several studies have recently been conducted on the remaining historical buildings in Kurose Town. One such study by Hojo and Tanigawa (2019) is an architectural study of the Kanemitsu Sake Brewery buildings. As for research on administrative services in Kurose Town, a study by Kitano and Uda (2003) can be highlighted. They are researchers at Hiroshima International University, which has a campus in Kurose-cho, and in their research, they used a GIS application to study the service delivery system of kindergartens and nursery schools, focusing on the distribution of facilities. For the official history of Kurose-cho, which was compiled before the merger with Higashihiroshima City, a series of official history books called Kurosecho-shi (2000) exists, which continues to be sold at the Culture Division of the Lifelong Learning Department of Higashihiroshima City government. These formal historical narratives share information regarding events before and up to the Edo period.

To summarize the related research so far, although there are many studies on Kurose Town based on other academic disciplines, the author could not find any studies on the government services of the Kurose Town area after the municipal merger in the field of public administration. The present study provides new insights into research on customers' direct experience related with customer satisfaction based on the managerial perspective, especially regarding the satisfaction of counter services provided in the municipal government's branch offices.

\section{Methods}

Self-administered questionnaires were distributed to customers at the Kurose branch office of the Higashihiroshima City government after they completed their business at the counter. The questionnaire was four pages long. The questionnaire items were arranged across three factor groups, including those for hardware (e.g. physical office aspects), software (e.g. staff responses), and services (e.g. administrative services) ${ }^{1}$ (see Mansor \& Razali, 2010). Then, questionnaire items belonging to four categories (A, B, C, and Y) were individually condensed into two principal components via principal component analysis ( $\mathrm{A}-\mathrm{C}$ and a group of questions related to the dependent variable Y; a list of these questions is shown in Table 1). The questionnaire also asked respondents for some personal information (e.g. age and gender) and posed some general open-ended questions about both the survey and the city government. Afterwards, two principal components in each category were used as explanatory variables in a multiple regression analysis. The first component from the Y category question items was set as the dependent variable. This type of two-stage

\footnotetext{
1 This position is based on the premise that governments view citizens as customers. It should be noted that the target population represents various aspects in public administration, such as citizens, voters, partners, and customers (Thomas, 2013).
} 
Table 1 Outline of survey question items

\begin{tabular}{lc}
\hline Concept Groups & Question Items \\
\hline A) Office hardware (buildings, tables, chairs, & AQ1 (Q3_1) Location (access from home) \\
lighting, and others) & AQ2 (Q3_2) Tables and chairs \\
& AQ3 (Q3_3) Indoor atmosphere \\
& AQ4 (Q3_4) Lighting \\
& AQ5 (Q3_5) Smoking restrictions (non-smoking) \\
& AQ6 (Q3_6) Toilets \\
& BQ1 (Q3_7) Length of time to complete customer \\
requests & BQ2 (Q3_8) Courteousness of the staff in charge \\
B) Office software (customer service provided by & BQ3 (Q3_9) Ease of consultation and asking the \\
the staff at the counter) & staff in charge questions \\
& BQ4 (Q3_10) Ease of understanding oral explana- \\
tions from the officer in charge (speed) & BQ5 (Q3_11) Clarity of explanation given by the \\
officer in charge (content) \\
CQ1 (Q4_1) Customer requests were completed \\
CQ2 (Q4_2) The problem was solved after this visit \\
to the branch office \\
CQ3 (Q4_3) The worries and concerns of customers \\
were alleviated after this visit to the branch office \\
YQ1 (Q5_1) Level of customer satisfaction with \\
their experiences at the branch office \\
YQ2 (Q5_2) Convenience of the administrative \\
services provided at the branch office \\
YQ3 (Q5_3) The Kurose town district is a good \\
place to live \\
\hline
\end{tabular}

analysis was previously referred to as a 'selective principal component regression analysis' by Kawasaki et al. (2014). ${ }^{2}$

The author and research collaborators (third-year students majoring in public administration) conducted the survey on six business days (24-31 August 2020). Desks were placed on the opposite side of the office counter such that respondents could complete their questionnaires on the spot. This resulted in a total of 240 respondents. Approximately 510 flyers containing survey outlines and thank you gifts for participating in the survey were submitted to the branch office. Of the 510 flyers, around 110 remained after the survey period, indicating that close to 400 were distributed. Based on these data, the survey participation rate was approximately $60 \%$.

\footnotetext{
${ }^{2}$ Bouckaert and Van de Walle (2003) defined the difference between 'hard indicators', such as resources and outputs, and 'soft indicators', such as citizen and user satisfaction targets. In this study, the software was considered a human aspect of the counter service provision, that is, on a more concrete level.
} 


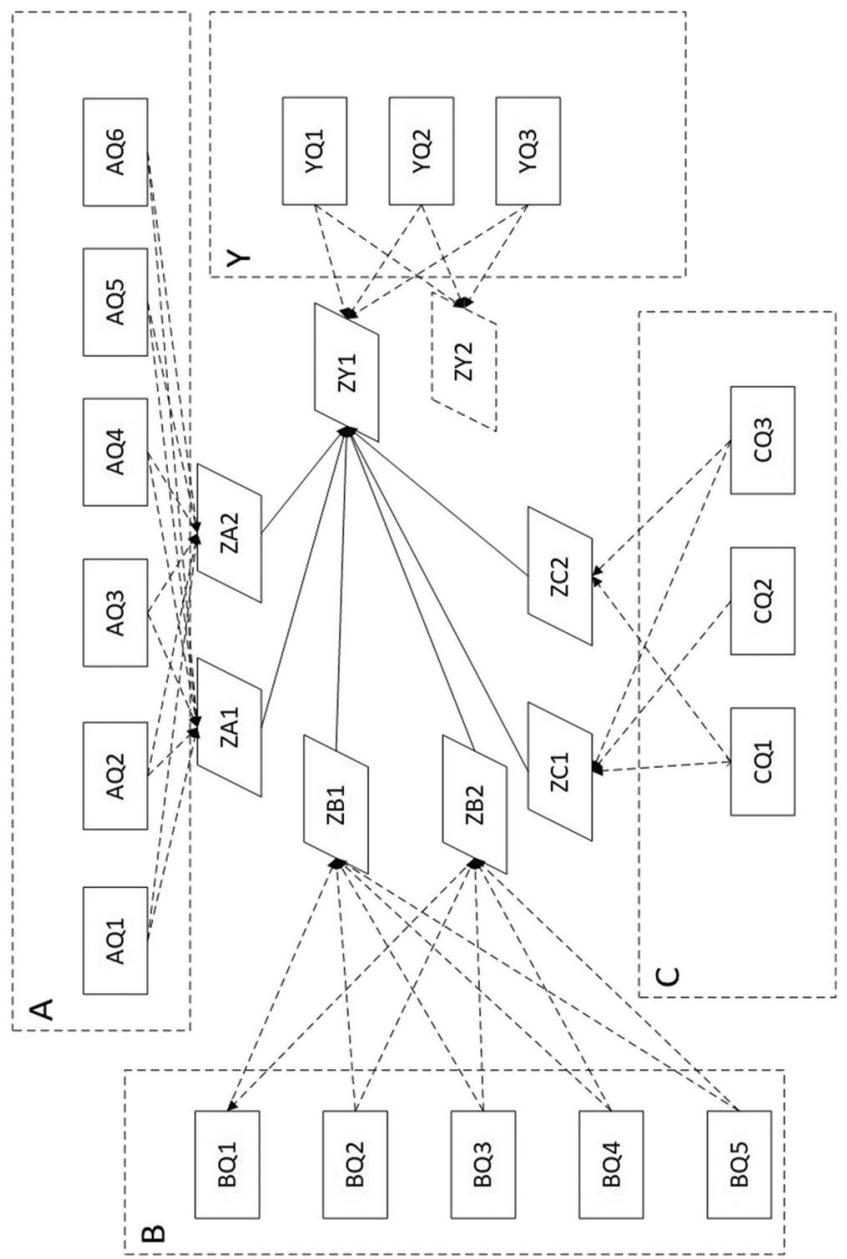

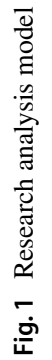


Table 2 Number of survey participants (August 2020)

\begin{tabular}{llll}
\hline Day of the Month & Weekday & Count & Ratio \\
\hline 25 & Tuesday & 37 & $18.0 \%$ \\
26 & Wednesday & 41 & $20.0 \%$ \\
27 & Thursday & 33 & $16.1 \%$ \\
28 & Friday & 39 & $19.0 \%$ \\
31 & Monday & 55 & $26.8 \%$ \\
Total & & 205 & $100.0 \%$ \\
\hline
\end{tabular}

A total of 35 visitors participated in the survey on the 24 th (Monday).

Figure 1 shows the assumed relationships between customer satisfaction with the counter services at municipal branch offices based on the abovementioned questionnaire categories $(\mathrm{A}-\mathrm{C})$, the explanatory variables, and the items in group $\mathrm{Y}$; the explained variable and the first and second principal components were synthesised in the principal component analysis based on each category.

\section{Results}

We obtained a total of 240 responses during the six-day survey period. However, only Counter 1 was surveyed on the first day (the 24th). After confirming that the number of respondents was likely to be lower than expected, the survey period was extended by one full day. The study scope was also expanded to include customers at Counters 1 through 4 . In this regard, the following analysis excluded responses from the first day, instead, covering one week beginning on the 25th.

Table 2 shows the number of respondents on each day. As displayed, the fewest were surveyed on Thursday (27th), while the most were surveyed on Monday (31st). However, the 31 st was also the last day of the month, which is generally associated with increased visitor numbers. Table 3 presents information on respondents' gender and age. Considering the bottom row (total), it is apparent that the largest percentage of participants were in their $70 \mathrm{~s}$, at $22.9 \%$ of the total. Breaking this down by gender, the largest percentage of male participants $(23 ; 27.7 \%)$ were in their $70 \mathrm{~s}$, whereas the largest percentage of female participants were in their $60 \mathrm{~s}(25 ; 20.7 \%)$. Table 4 shows the number of respondents for each counter on each day.

Figure 2 illustrates the results of the principal component analysis for each question in category $Y$. The scores for the first and second components were added to the dataset as variables ZY1 and ZY2. Figure 2 also shows that YQ1 and YQ2 had significant effects on the first principal component, which was interpreted as 'experience satisfaction and convenience'.

The correlation coefficients between each of the question items in groups A to $\mathrm{C}$ and ZY1 are displayed in Table 5. The marked question items were selected and used in the following principal components analysis for each group. Figure 3 shows the results of the principal component analysis for each question in category A. The scores for the first and second components were added to the dataset as variables 


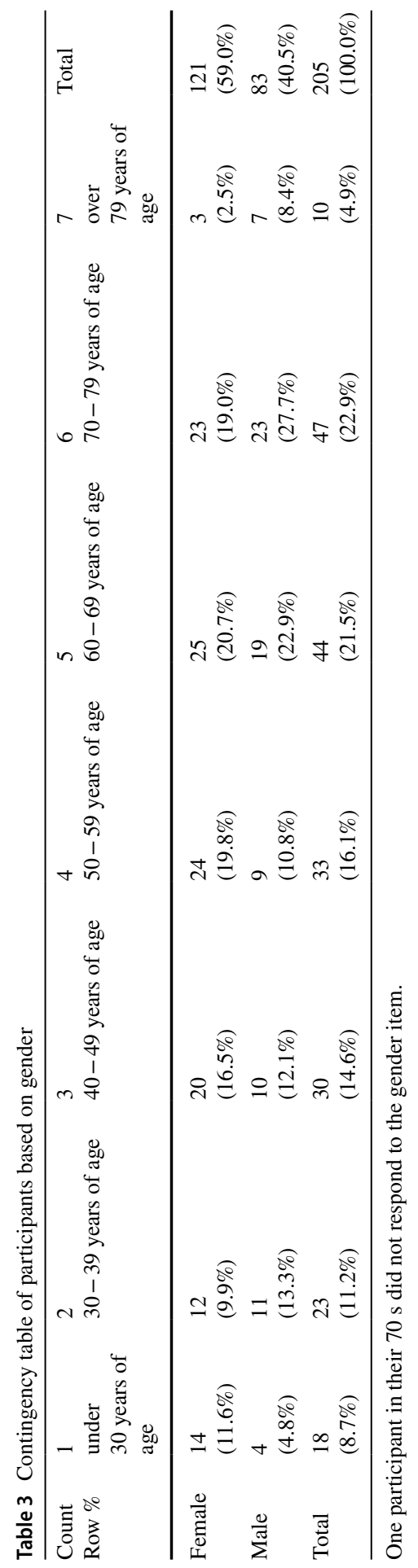


Table 4 Contingency table concerning the weekday and number of participants from each counter

\begin{tabular}{lllllll}
\hline $\begin{array}{l}\text { Counter Number } \\
\text { Row } \%\end{array}$ & 1 & 2 & 3 & 4 & $\begin{array}{l}\text { Multiple } \\
\text { Counters }\end{array}$ & Total \\
\hline $25 / 8$ & 23 & 2 & 2 & 9 & 1 & 37 \\
Tuesday & $(62.2 \%)$ & $(5.4 \%)$ & $(5.4 \%)$ & $(24.3 \%)$ & $(2.7 \%)$ & $(100.0 \%)$ \\
$26 / 8$ & 24 & 1 & 5 & 9 & 2 & 41 \\
Wednesday & $(58.5 \%)$ & $(2.4 \%)$ & $(12.2 \%)$ & $(22.0 \%)$ & $(4.9 \%)$ & $(100.0 \%)$ \\
$27 / 8$ & 23 & 3 & 3 & 2 & 2 & 33 \\
Thursday & $(69.7 \%)$ & $(9.1 \%)$ & $(9.1 \%)$ & $(6.1 \%)$ & $(6.1 \%)$ & $(100.0 \%)$ \\
$28 / 8$ & 35 & 0 & 2 & 1 & 1 & 39 \\
Friday & $(89.7 \%)$ & $(0.0 \%)$ & $(5.1 \%)$ & $(2.6 \%)$ & $(2.6 \%)$ & $(100.0 \%)$ \\
$31 / 8$ & 42 & 1 & 3 & 7 & 2 & 55 \\
Monday & $(76.4 \%)$ & $(1.8 \%)$ & $(5.5 \%)$ & $(12.7 \%)$ & $(3.6 \%)$ & $(100.0 \%)$ \\
Total & 147 & 7 & 15 & 28 & 8 & 205 \\
\hline
\end{tabular}

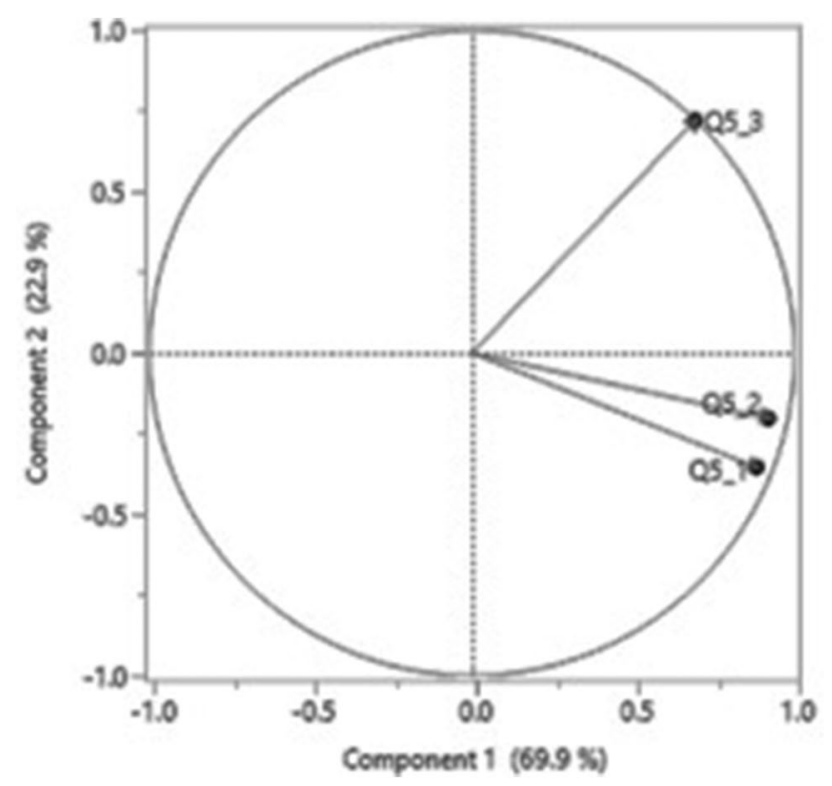

Fig. 2 Factor loadings related to Y (overall customer satisfaction with counter services)

ZA1 and ZA2. As shown, AQ2 (Q3_2) and AQ3 (Q3_3) had significant effects on the first principal component, and they were interpreted as 'office equipment inside the building'. Thus, component 2 can be interpreted as the 'branch office location', if focusing on the position of AQ1 (Q3_1).

Figure 4 presents the results of the principal component analysis for each question in category B. As shown, the scores for the first and second components were added to the dataset as variables ZB1 and ZB2. Figure 4 indicates that BQ2 (Q3_8) to BQ5 (Q3_11) had significant effects on component 1 (ZB1), which was interpreted as 
Table 5 Co-relationship between component $\mathrm{ZY} 1$ and the question items

\begin{tabular}{ll}
\hline Question Items & $r$ \\
\hline AQ1 (Q3_1)* & $0.417 * *$ \\
AQ2 (Q3_2)* & $0.418^{* *}$ \\
AQ3 (Q3_3)* & $0.427 * *$ \\
AQ4 (Q3_4) & $0.365^{* *}$ \\
AQ5 (Q3_5) & $0.215^{* *}$ \\
AQ6 (Q3_6) & $0.182^{* *}$ \\
BQ1 (Q3_7)* & $0.497 * *$ \\
BQ2 (Q3_8)* & $0.566^{* *}$ \\
BQ3 (Q3_9)* & $0.612^{* *}$ \\
BQ4 (Q3_10)* & $0.523^{* *}$ \\
BQ5 (Q3_11)* & $0.581^{* *}$ \\
CQ1 (Q4_1) & $0.343 * *$ \\
CQ2 (Q4_2)* & $0.485^{* *}$ \\
CQ3 (Q4_3)* & $0.440^{* *}$ \\
\hline
\end{tabular}

* Questionnaire items with correlation coefficients of 0.4 or higher were used in the principal component analysis for each category.

$* * p<0.01$.

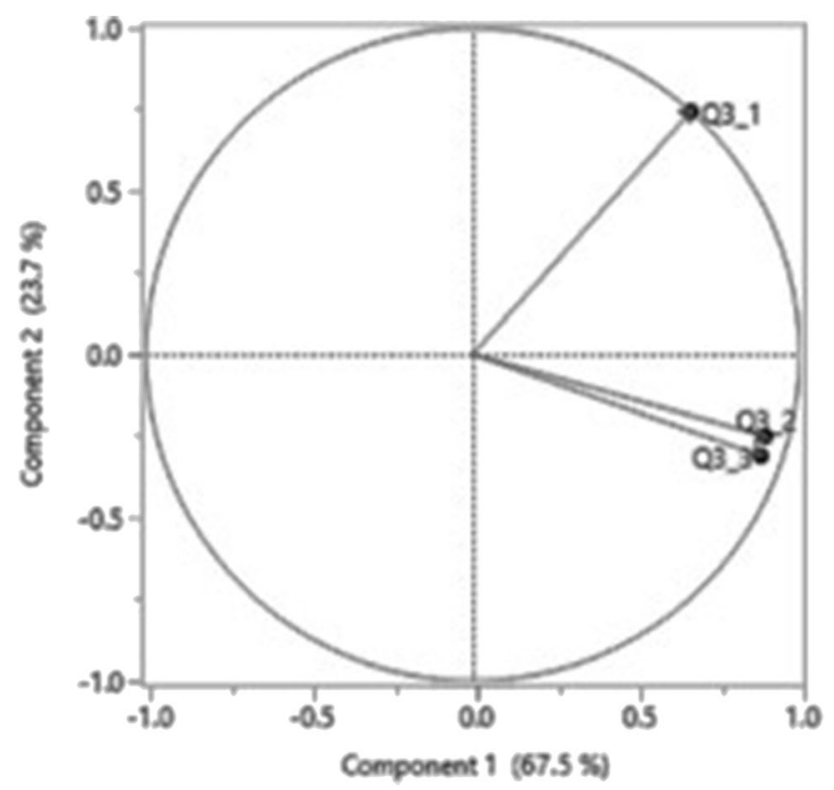

Fig. 3 Factor loadings related to A

'how officers deal with and explain issues to customers at the counter'. Therefore, component 2 (ZB2) can be interpreted as 'waiting time at the branch office' if focusing on the position of BQ1 (Q3_7). 


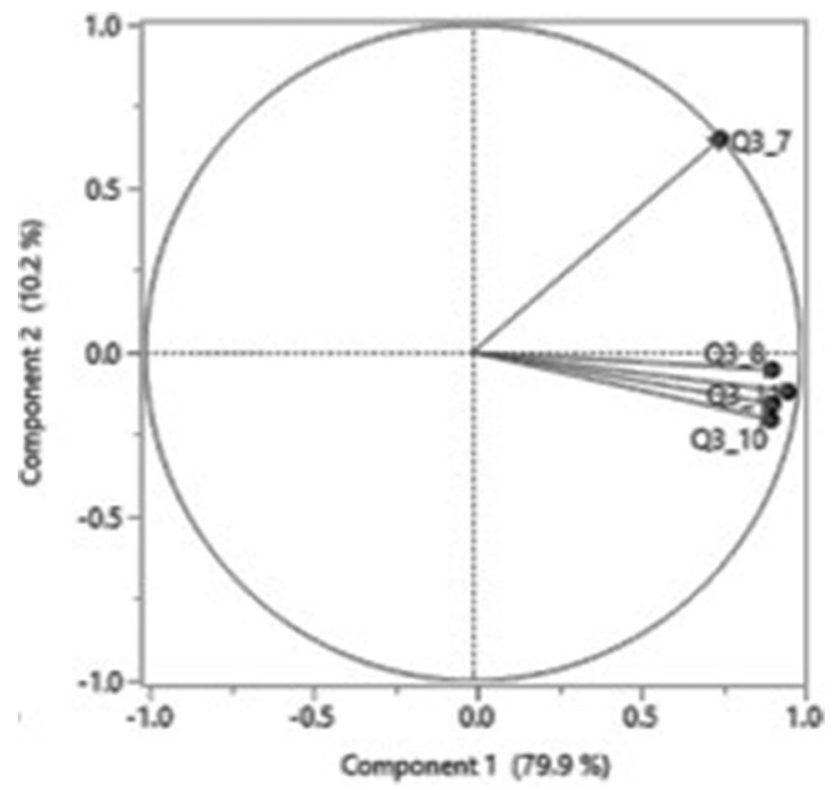

Fig. 4 Factor loadings related to B

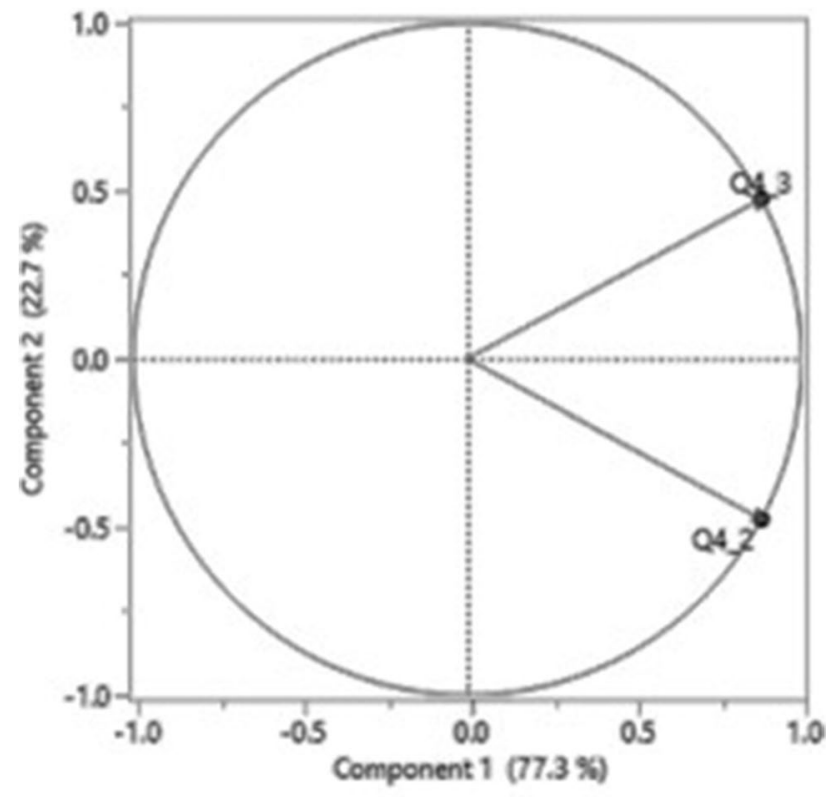

Fig. 5 Factor loadings related to $\mathrm{C}$ 
Table 6 Multiple regression predicting overall customer satisfaction (component ZY1): Model 1 (ZY1 was calculated from YQ1, YQ2, and YQ3)

\begin{tabular}{lllll}
\hline & Zero Order $r$ & $\beta$ & $p$ & VIF \\
\hline ZA1 & $0.508^{* *}$ & $0.19^{* *}$ & 0.0026 & 1.53 \\
ZA2 & 0.104 & $0.11^{*}$ & 0.0260 & 1.00 \\
ZB1 & $0.623^{* *}$ & $0.38^{* *}$ & $<0.0001$ & 1.82 \\
ZC1 & $0.526^{* *}$ & $0.26^{* *}$ & $<0.0001$ & 1.38 \\
\hline
\end{tabular}

$R^{2}=0.48$; Adjusted $R^{2}=0.47$;

Figure 5 presents the results of the principal component analysis for each question in category $\mathrm{C}$. As indicated, the scores for the first and second components were added to the dataset as variables ZC1 and ZC2. Also shown in Fig. 5, component 1 was interpreted as 'solving customer problems and concerns'. Then, if focusing on the position of CQ3 (Q4_3), component 2 can be interpreted as 'solving customer problems based on feelings and emotions'.

Table 6 presents the results of the multiple regression analysis on ZY1, which was generated from the $\mathrm{Y}$ group of explained variables using the variable increasing and decreasing method with synthetic variables ZA1, ZA2, ZB1, ZB2, ZC1, and ZC2, which were generated from the categories of explanatory variable question groups. The standardized partial regression coefficients in Table 6 indicate that ZB1 was the highest at 0.38 (significant at the $1 \%$ level). Defined as 'how officers deal with and explain issues to customers at the counter', ZB1 was the most important variable for the explained variable (ZY1). Next, ZC1 and ZA1 had positive effects on the objective variable, in that order (significant at the $1 \%$ level). Since each variance inflation factor (VIF) was under 2.00, independence among the selected explanatory variables was considered to be maintained to a certain degree.

$$
* * p<0.01 ; * p<0.05 \text {. }
$$

Each questionnaire item in the Y group, which contained the explained variables, were then re-examined. A correlation analysis of ZY1 with YQ1, YQ2, and YQ3 showed respective correlation coefficients of 0.882, 0.917, and 0.691 (all significant at the $1 \%$ level). Excluding YQ3, which showed a low correlation with ZY1, ${ }^{3}$ a new principal component analysis was performed on the $\mathrm{Y}$ group, while a multiple regression analysis using the first principal component of the calculated composite variables (ZY2_1 and ZY2_2) was conducted in the same way as before (see Table 7). Here, the adjusted $R^{2}$ increased to 0.51 , while the $\beta$ of $\mathrm{ZB} 1$ increased to 0.45. In Model 2, each VIF was under 2.00. Therefore, independence among the selected explanatory variables was maintained to a certain degree.

YQ3 concerns the liveability of the Kurose town area of Higashihiroshima City. An IEEE proceeding of Yu et al. (2011) considered the relationship between family income, life satisfaction, and satisfaction with the government based on continuing

\footnotetext{
3 The method of performing a principal component analysis on multiple question items belonged to several categories, while the multiple regression analysis using the combined principal component scores as explanatory variables was also mentioned in Everitt (2005). The risk of multicollinearity between each question item was avoided by performing the principal component analysis first.
} 
Table 7 Multiple regression predicting overall customer satisfaction (component ZY1): Model 2 (excluding the YQ3 item)

\begin{tabular}{lllll}
\hline & Zero Order $r$ & $\beta$ & $p$ & VIF \\
\hline ZA1 & $0.512^{* *}$ & $0.16^{* *}$ & 0.0079 & 1.53 \\
ZA2 & 0.092 & $0.10^{*}$ & 0.0036 & 1.00 \\
ZB1 & $0.666^{* *}$ & $0.45^{* *}$ & $<0.0001$ & 1.82 \\
ZC1 & $0.525^{* *}$ & $0.23^{* *}$ & $<0.0001$ & 1.38 \\
\hline
\end{tabular}

$R^{2}=0.52$; Adjusted $R^{2}=0.51$;

$* * p<0.01 * p<0.05$

research in 21 counties/cities from 2004 to 2010, excluding 2006. Results showed a strong co-relationship between satisfaction with local government and life satisfaction in $2005(r=-0.55, p<0.01)$ (Yu et al., 2011, p. 1211). In the Kurose branch office study, local liveability was weakly related to satisfaction with the local government branch office. We would like to further examine the relationship with life satisfaction by replacing the questions in group $\mathrm{Y}$ and adding other relevant items.

\section{Discussion and Conclusion}

This study at the Kurose branch office of the Higashihiroshima City government aimed to find determinants of customers satisfaction with the counter service provided at the branch offices in municipalities in Japan. The survey was conducted on six business days (24-31 August 2020) and resulted in a total of 240 responses. Based on the remaining survey flyers (110 of 510) once the research period concluded, the participation rate was approximately 60\%. The sample for the principal component analysis and multiples regression analysis was composed of the 205 valid questionnaires collected from 25 to 31 August, over five business days.

The questionnaire was designed to assess factors (explanatory variables) and items related to customer satisfaction with the counter services provided at the branch office. There were also some open-ended items about the survey itself and local city policies. Questionnaire items were distributed across four categories (A, B, $\mathrm{C}$, and $\mathrm{Y}$ ), then individually condensed into pairs of two principal components via principal component analysis. Next, two principal components from each category were submitted to a multiple regression analysis as explanatory variables. This twostage analysis (referred to as selective principal component regression analysis) was implemented based on two models. Among the explanatory variables (i.e. A-C), the regression analysis showed that in group B, 'software related to officers' human factors' was the most important of the dependent $\mathrm{Y}$ variables, followed by groups $\mathrm{C}$ and A (adjusted $R^{2}$ value of 0.51 ; Model 2 ). The $\beta$ of ZB1 was 0.45 . According to both Models 1 and 2, the most important variables were staff responses and explanations (group B), thus supporting the results of a previous study conducted in Malaysia (Mansor \& Razali, 2010).

After the research was concluded, an online questionnaire survey was conducted among the users of the ward office in Osaka City (Moteki, 2021). The 
principal component scores for the three factor categories mentioned above (A-C) were also statistically significant variables in the last multiple regression analysis, using the dataset of the Osaka City survey. There were differences in the results between this study's examination of the Kurose branch office and that on the ward offices of Osaka City. The latter indicated that C (service delivery quality) was more important than B (customer service provided by the counter staff). The differences between the results of the two studies may be due to differences in the services provided by the branch and the ward offices of ordinance-designated cities, as well as differences related to the attributes of their customers. Comparing the two studies alone may not provide an accurate picture of the factors that create this difference; we would like to explore the relevant factors through a survey in another municipality and a follow-up survey in the same municipality.

This study focused on three categories, including hardware, customer service provided by the counter officer, and service delivery quality (groups A-C). Future research may need to implement additional aspects related to other customer satisfaction factors, thus establishing a more explanatory model. Items with less than 0.4 correlation coefficients with the composite variables (comprising question items belonging to the $\mathrm{Y}$ category; that is, the results category) were not subjected to the principal component analysis within a given category. More appropriate question items may produce different results or lead to a model with a higher coefficient of determination ( $R^{2}$ value). We would like to explore models and questionnaires that can better grasp customer satisfaction at government offices by conducting a follow-up survey in the same Kurose branch office. With the cooperation of the Town and Gown Liaison Office in the affiliated university, additional questionnaire surveys are planned to be conducted in Higashihiroshima City Hall from August 23 to 27, 2021. By comparing the results of these three surveys, the impact of different characteristics of government organizations on the determinants of customer satisfaction can be examined. In addition, it would be beneficial to focus on employee satisfaction in government offices. In public administration, service delivery is also a major task, and as the results of this study show, human factors have a significant impact on customer satisfaction. In this sense, ensuring the satisfaction of the administrative employees involved in service delivery should also be an important issue. Vermeeren et al. (2011) expressed this as satisfaction mirror. Educating employees about the significance of a company's business programs is sometimes described in business management as internal marketing. We would like to examine this aspect of government services in the future.

Acknowledgements The town and gown relation office of an affiliated institution assisted us in conducting this research. More specifically, the office coordinated the research plan as conducted at the Kurose branch office of the Higashihiroshima city government. The government also provided extensive assistance in securing survey responses from residents of the Kurose town district.

Funding This work was supported by a subsidy for English editing services provided by the affiliated university.

Data Availability The datasets generated and/or analysed during the current study are not publicly available due to the data anonymity guarantee given to the surveyed branch office and municipal government. 
The aggregated statistics of each question items are available from the corresponding author on reasonable request.

\section{Declarations}

Competing Interests The author declares no competing interests.

Open Access This article is licensed under a Creative Commons Attribution 4.0 International License, which permits use, sharing, adaptation, distribution and reproduction in any medium or format, as long as you give appropriate credit to the original author(s) and the source, provide a link to the Creative Commons licence, and indicate if changes were made. The images or other third party material in this article are included in the article's Creative Commons licence, unless indicated otherwise in a credit line to the material. If material is not included in the article's Creative Commons licence and your intended use is not permitted by statutory regulation or exceeds the permitted use, you will need to obtain permission directly from the copyright holder. To view a copy of this licence, visit http://creativecommons.org/licen ses/by/4.0/.

\section{References}

Abe, H. (2004). Kinsei noson chiiki shakai-shi no kenkyu (Study of modern rural community history). Keiso Shobo Publishing.

Agus, A., Barker, S., \& Kandampully, J. (2007). An exploratory study of service quality in the Malaysian public service sector. International Journal of Quality \& Reliability Management, 24(2), 177-190. https://doi.org/10.1108/02656710710722284

Akinboade, O. A., Kinfack, E. C., \& Mokwena, M. P. (2012). An analysis of citizen satisfaction with public service delivery in the Sedibeng district municipality of South Africa. International Journal of Social Economics, 39(3), 182-199. https://doi.org/10.1108/03068291211199350

Bouckaert, G., \& Van de Walle, S. (2003). Comparing measures of citizen trust and user satisfaction as indicators of "good governance": Difficulties in linking trust and satisfaction indicators. International Review of Administrative Sciences, 69(3), 329-343. https://doi.org/10.1177/0020852303 693003

Cripps, H., Ewing, M., \& McMahon, L. (2004). Customer satisfaction in local government: The case of the restructured city of Perth, Australia. Journal of Nonprofit and Public Sector Marketing, 12(1), 1-22. https://doi.org/10.1300/J054v12n01_01

Everitt, B. S. (2005). An R and S-PLUS companion to multivariate analysis. Springer Science \& Business Media.

Higashihiroshima City Government. (2016). Higashihiroshima-shi no Purofiru (Profile of Higashihiroshima City). Higashihiroshima City Website. Retrieved November 5, 2021, from https://www.city. higashihiroshima.lg.jp/soshiki/somu/2_1/5/5071.html

Higashihiroshima City Government. (2020). 2020 (Reiwa 2) nendo Owaza betsu Jinko oyobi Nenrei betsu Jinko-to (Population by area and age in 2020). Higashihiroshima City Website. Retrieved November 5, 2021, from https://www.city.higashihiroshima.lg.jp/shisei/tokeijoho/1/24467.html

Hiroshima Prefectural Government. (2007). Kazahaya no Ura (Kazahaya seashore). Website. Retrieved November 5, 2021, from http://www.hiroshima-bunka.jp/modules/newdb/detail.php?id=770

Hojo, T., \& Tanigawa, D. (2019). Higashihiroshima-shi Kurose-cho kanemitsu shuzo ni okeru rekishiteki haikei to kenchiku-teki kachi: Kurosemachi ni yuiitsu aru shuzo no hozon to saisei ni kansuru kenkyū (The historical background and architectural value of Kanemitsu Sake Brewery in Kurose, Higashihiroshima City: Study on preservation and reproduction of the Sake Brewery only in Kurose). Nihonkenchikugakkai Chugoku 42, 887-890. https://ci.nii.ac.jp/naid/40021834795/

Hsiao, C. T., \& Lin, J. S. (2008). A study of service quality in public sector. International Journal of Electronic Business Management, 6(1), 29-37. https://citeseerx.ist.psu.edu/viewdoc/download? doi=10.1.1.470.6991\&rep=rep1\&type $=$ pdf 
Huque, A. S., \& Hayllar, M. R. (1999). The limits of customer satisfaction: The case of the Companies Registry Trading Fund in Hong Kong. Asian Review of Public Administration, 11(2), 100-113.

Kawasaki, S., Takahashi, T., \& Suzuki, K. (2014). The effect of autonomous career actions on self-career formation from the viewpoint of quality management. Proceedings of International Conference on Quality '14, Tokyo, 152-163.

Kelly, J. M. (2005). The dilemma of the unsatisfied customer in a market model of public administration. Public Administration Review, 65(1), 76-84. https://doi.org/10.1111/j.1540-6210.2005.00432.x

Kelly, J. M., \& Swindell, D. (2002). A multiple-indicator approach to municipal service evaluation: Correlating performance measurement and citizen satisfaction across jurisdictions. Public Administration Review, 62(5), 610-621. https://doi.org/10.1111/1540-6210.00241

Kitano, S., \& Uda, J. (2003). Kureshi Kurose Cho ni okeru yōchien to hoikujo no sābisu teikyō taisei ni kansuru kenkyū (A study for analyzing the provision of the early childhood services in Kure-City and Kurose-Cho). Yonen Kyoiku Kenkyu Nenpo (Early Childhood Education Annual Report), 25, 63-70. https://ci.nii.ac.jp/naid/110004667240/

Kumano Town. (2009). Madoguchi Sabisuanketo Chosa Kekka (Results of Questionnaire on Counter Service). Retrieved November 5, 2021, from https://www.town.kumano.hiroshima.jp/www/conte nts/1248846633875/index.html

Kurose Town. (2001). Dainiji Kurose Cho choki Sogo Keikaku (The Second Term Long-Term Comprehensive Plan for Kurose Town), Kurose Town.

Kurosecho-shi-hen-san Iinkai. (2003). Kurosecho-shi (History of Kurose Town). Kurose Town. https://ci. nii.ac.jp/ncid/BA65253016

Maeda, I. (2005). Jissen Kanja Manzoku-do Appu (Practical improvement of patient satisfaction). Nihon Hyoronsha.

Manary, M. P., Boulding, W., Staelin, R., \& Glickman, S. W. (2013). The patient experience and health outcomes. New England Journal of Medicine, 368(3), 201-203. https://doi.org/10.1056/NEJMp 1211775

Mansor, N., \& Razali, C. H. C. M. (2010). Customers' satisfaction towards counter service of local authority in Terengganu. Malaysia. Asian Social Science, 6(8), 197. https://doi.org/10.5539/ass.v6n8p197

Morgeson, F. V. (2012). Expectations, disconfirmation, and citizen satisfaction with the US federal government: Testing and expanding the model. Journal of Public Administration and Research Theory, 23(2), 289-305. https://doi.org/10.1093/jopart/mus012

Moteki, Y. (2021). Customer satisfaction with services at the ward offices of Osaka City Government. Chihoujichi Kenkyu (Journal of Urban Management and Local Government Research), 36(1), 91-103.

Moteki, Y. (2015). Gyosei hyoka bumu-go no jichitai ni okeru seisaku hyoka seido no henka to kadai: 'Hyoka fuan' gainen o tegakari ni shita zenkoku chōsa ni motodzuku ‘hyoka dsukare' no kento (Changes and challenges after the evaluation boom years in Japanese local governments: An examination of evaluation exhaustion based on the data from a nationwide survey focusing on the concept of evaluation anxiety). Chihoujichi Kenkyu (journal of Urban Management and Local Government Research), 30(2), 1-17.

Noda, Y. (2013). Shimin Manzoku-do no Kenkyū (Research on citizen satisfaction). Nippon Hyoronsha.

Noda, Y. (2014). Nonlinear effects on citizen satisfaction and different levels of governments in Japan. Asian Review of Public Administration, 25(1), 74-91. https://doi.org/10.1007/978-3-319-31816-5_ 3265-1

Noda, Y. (2019). Citizen expectations and satisfaction of service performance: Lessons from subnational governments in Japan. Asia Pacific Journal of Public Administration, 41(3), 142-156. https://doi. org/10.1080/23276665.2019.1658361

Ogaki City. (2014). Shin Chosha Kensetsu Shimin Anketo Chosa Hokoku-sho (Citizen Questionnaire Survey Report for Considering New Government Building Construction). Retrieved November 5, 2021, from https://www.city.ogaki.lg.jp/cmsfiles/contents/0000017/17968/anketoshuukei

Oliver, R. L., \& Winer, R. S. (1987). A framework for the formation and structure of consumer expectations: Review and propositions. Journal of Economic Psychology, 8(4), 469-499. https://doi.org/10. 1016/0167-4870(87)90037-7

Oliver, R. L. (2015). Satisfaction: A behavioral perspective on the consumer (2nd ed.). Routledge.

Ono, J. (2010). Kokyaku Manzoku (CS) no Chishiki (Knowledge of customer satisfaction [CS]). Nihon Keizai Shinbum Shuppansha.

Parasuraman, A., Zeithaml, V. A., \& Berry, L. L. (1988). SERVQUAL: A multiple-item scale for measuring consumer perceptions of service quality. Journal of Retailing, 64(1), 12-40. 
Rhee, S. K., \& Rha, J. Y. (2009). Public service quality and customer satisfaction: Exploring the attributes of service quality in the public sector. The Service Industries Journal, 29(11), 1491-1512. https://doi.org/10.1080/02642060902793441

Surapto, D. (2014). The influence of people satisfaction on services organization public performance of village district in south of Tangerang. Journal of Management and Business, 13(2), 169-176. https://doi.org/10.24123/jmb.v13i2.243

Tabuchi, Y. (2010). Chihou Jichitai ni okeru Gyosei Hyoka 12 Nen no Ayumi to Kongo no Kadai (Progress of public sector evaluation in local government in 12 years and future prospects). Mitsubishi Sogo Kenkyujo Hou (Mitsubishi Research Institute Report), 53, 30-53. https://ci.nii.ac.jp/naid/ 40017183196

Takahashi, T., \& Kawasaki, M. (2019). Anketo ni yoru Chosa to Kaso Jikken: Kokyakumanzoku-do no Haaku to Kojo (Survey and virtual experiments by questionnaire: Understanding and improving customer satisfaction). Nikkagiren.

Thomas, J. C. (2013). Citizen, customer, partner: Rethinking the place of the public in public management. Public Administration Review, 73(6), 786-796. https://doi.org/10.1111/puar.12109

Van Ryzin, G. G. (2004). Expectations, performance, and citizen satisfaction with urban services. Journal of Policy Analysis and Management, 23(3), 433-448. https://doi.org/10.1002/pam.20020

Van Ryzin, G. G. (2006). Testing the expectancy disconfirmation model of citizen satisfaction with local government. Journal of Public Administration Research and Theory, 16(4), 599-611. https://doi. org/10.1093/jopart/mui058

Van Ryzin, G. G., \& Immerwahr, S. (2007). Importance-performance analysis of citizen satisfaction surveys. Public Administration, 85(1), 215-226. https://doi.org/10.1111/j.1467-9299.2007.00641.x

Van Ryzin, G. G., Muzzio, D., Immerwahr, S., Gulick, L., \& Martinez, E. (2004). Drivers and consequences of citizen satisfaction: An application of the American customer satisfaction index model to New York City. Public Administration Review, 64(3), 331-341. https://doi.org/10.1111/j.1540-6210. 2004.00377.x

Vermeeren, B., Kuipers, B., \& Steijn, B. (2011). Two faces of the satisfaction mirror: A study of work environment, job satisfaction, and customer satisfaction in Dutch municipalities. Review of Public Personnel Administration, 31(2), 171-189. https://doi.org/10.1177/0734371X11408569

Wagenheim, G. D., \& Reurink, J. H. (1991). Customer service in public administration. Public Administration Review, 51(3), 263-269. https://doi.org/10.2307/976950

Wilson, A., Zeithaml, V. A., Bitner, M. J., \& Gremler, D. D. (2021). Services marketing: Integrating customer focus across the firm (4th ed.). Mc Graw Hill.

Wisniewski, M. (2001). Assessing customer satisfaction with local authority services using SERVQUAL. Total Quality Management, 12(7-8), 995-1002. https://doi.org/10.1080/09544120100000026

Wolf, C. P. X. P., \& Jason, A. (2014). Defining patient experience. Patient Experience Journal, 1(1), 7-19. https://doi.org/10.35680/2372-0247.1004

Yamaoka, Y. (2015). Koko made Wkaru Shisaku Manzokudo Chosa: Gyosei no Keiei Hinshitsu Kojo wo Mezashite (Understanding Program Satisfaction Survey: Towards improving management quality in public administration). V2 Corporation.

Yamaoka, Y., \& Hideshima, E. (2012). Keiei Hinshitsu ni okeru Joho Manejimento no Shiten kara mita Chihojichitai no Shisaku Manzokudochōsa ni kansuru Kenkyu (A Study on Citizen Satisfaction Survey from the Perspective of Information Management in Quality). Nihon Keiei Hinshitsu Gakkai Shi Onrain (Journal of Japan Association of Performance Excellence Online), 6(1), 3-19. https:// doi.org/10.11199/japeoj.6.3

Yu, Z., Bo, W., \& Shu, L. (2011, September). The dynamic relationship between satisfaction with local government, family income, and life satisfaction in China: A 6-year perspective. International Conference on Management Science \& Engineering 18th Annual Conference Proceedings, 1207-1214. https://ieeexplore.ieee.org/document/6070109

Zeithaml, V. A. (1988). Consumer perceptions of price, quality, and value: A means-end model and synthesis of evidence. Journal of Marketing, 52(3), 2-22. https://doi.org/10.1177/002224298805200 302

Publisher's Note Springer Nature remains neutral with regard to jurisdictional claims in published maps and institutional affiliations. 